\title{
Treatment of Medical Wastewater by Moving Bed Bioreactor System
}

\author{
Yaser I. Jasem¹, Ghufran F. Jumaha², Ali Hadi Ghawi \\ 1 Department of Chemical Engineering, College of Engineering, University of Diyala, Iraq \\ 2 Department of Civil Engineering, University of Technology, Iraq \\ ${ }^{3}$ Department of Civil Engineering, College of Engineering, Al-Qadisiyah University, Iraq \\ * Corresponding author's e-mail:yaser_ij@yahoo.com
}

\begin{abstract}
The hospital wastewater is considered as a complex mixture, populated with microbial and a variety of toxic substances. The performance of EEC USA moving bed biofilm reactor (MBBR) with polyethylene media as biofilm support carrier, packaged wastewater treatment plant with a capacity of $250 \mathrm{~m}^{3} /$ day was evaluated for treating the wastewater from Al-Batul hospital of Baquba city in Iraq in terms of the organic matter and suspended solid removal, along with nitrification and microbial growth for medical wastewater. The test results showed that the average removal efficiency of biochemical oxygen demand $\left(\mathrm{BOD}_{5}\right)$, chemical oxygen demand (COD), and total suspended solid (TSS) were 79.5\%,74.5\%, and 78\%, respectively. The system offers good nitrification with the efficiency of $79 \%$. The system shows a weak formation of biomass on carriers, only $1.93 \mathrm{~g} \mathrm{TSS} / \mathrm{m}^{2}$ of media, corresponding to $32 \%$ of the suspended biomass in the reactor.
\end{abstract}

Keywords: MBBR, BOD removal, COD removal, SS removal.

\section{INTRODUCTION}

Several provenance of sewage could contribute to the load of pollutants discharged in water bodies, especially medical sewage (Tatiana et al., 2011). In general, hospitals are characterized by higher wastewater streams than conventional households (400-1200 1/bed.d vs. 100 1/capita.d) (Gautam et al., 2007; Suarez et al., 2009).

The hospital wastewater is considered as a complex mixture, populated with pathogenic microorganisms. The hospital wastewater additionally contains an assortment of harmful substances, for example, pharmaceuticals, radionuclide, solvents, and disinfectants for medical purposes in an extensive variety of concentrations due to laboratory and research activities or medicine excretion (Verlicchi et al., 2010). The contact of hospital poisons with aquatic ecosystems leads to the damage of the natural environment and creates a biological imbalance (Emmanuel et al., 2005; Kajitvichyanukul et al., 2006). The hospital waste poses a serious health hazard to the health workers, public and air flora in the area (Ekhaise and Omavwoya, 2008).

Wastewater treatment is a major term, which is utilized in relation to the processes and operation to reduce the harmful properties of wastewater in order to make it less hazardous to humankind and nature (Punmia et al., 2003).

Biological processes are a cost-effective and environmentally sound alternative to the chemical treatment of wastewater (Borkar et al., 2013). The activated sludge and trickling filters are two common technologies utilized for the biological treatment of sewage. A moving bed biological reactor (MBBR) is a combination of these two technologies. Two forms of biomass exist in an MBBR system, involving suspended flocks and a biofilm attached to carriers. It can be operated at high organic loads and it is less sensitive to hydraulic overloading (Pal et al., 2016). It is not quite the same as activated sludge due to retained biomass, attached to media. The process has been utilized for the treatment of both municipal and industrial wastewater. Today, there are around 600 MBBRs 
that have been introduced in 50 unique nations all around the world. Installations are executed for different treatment purposes such as organic removal, nitrification, and denitrification for both the municipal and industrial wastewater (McQuarrie et al., 2011); (Ødegaard, 2000).

Both the suspended and attached growth processes have their advantages and disadvantages. The attached growth method has been considered as most favorable due to small footprint, minimum equipment maintenance and simpler operation in relation to the suspended growth method (Westerling, 2014). Furthermore, the attached film system has no fouling, no need for backwash, and no need to return the sludge. The biofilm has a low hydraulic decline and a high specific area. The process offers flexible design, which is highly stable and resistant to a variety of shocks (Biswas et al. 2014). Due to these reasons, the moving bed biofilm reactor has been progressing by Anoxkaldnes in Norway in the late 1980s and early 1990s (Ødegaard, 1999).

The main aim of this study is to evaluate the performance of a MBBR compact system with polyethylene media as a biofilm support carrier in terms of the organic matter and suspended solid removal, along with the nitrification and microbial growth for the medical wastewater from AlBatool Teaching Hospital in Baquba city of Iraq.

\section{MARERIAL AND METHODS}

\section{Full-scale system and wastewater}

Experiments were done in the period from $1^{\text {st }}$ January 2017 to $15^{\text {th }}$ April 2017. The raw wastewater from Al-Batool hospital was used as the influent wastewater for all experimental works during this study. This work correlated with the operating continuous stages of a full-scale MBBR for the treatment of raw hospital wastewater, and then it was conducted at EEC USA packaged wastewater treatment plant with a capacity of 250 $\mathrm{m}^{3} /$ day, in the Al-Batool Teaching Hospital of Baquba city, Iraq. The system used was a packaged wastewater treatment plant that incorporates Assisted Moving Bed Biomedia, Tequatic Plus tertiary filtration (Tequatic Filter, and Ultraviolet Disinfection (UV). Figure 1 shows the schematic of EEC USA packaged MBBR system. The EEC wastewater treatment plant technology is based on assisted moving bed (AMB) process and includes two moving bed bioreactors in series, followed by an integral clarifier, all in a single, packaged plant.

Water is delivered to the MBBR via a feed pump located in the equalization tank on site to the first chamber of the system. The first chamber functions as a "roughing reactor" to shave peak wastewater loads and remove the majority of influent biological oxygen demand (BOD) from the wastewater; the second chamber is a polishing reactor designed to reach the required effluent BOD; and the third chamber is a combined clarification and settling system designed to remove total suspended solids (TSS) from the treated water to the sludge tank, as well as to recycle the residual BOD back to the first chamber for reprocessing. Each reactor was aerated via a coarse bubble air distribution, located at the bottom. High-efficiency regenerative blowers were used to supply air in order to provide oxygen to the biomass and mixing of biomedia.

The (AMB) Biomedia was a specially designed biofilm carrier element which is free floating in each of the reactors and has a large surface area effectively, $500 \mathrm{~m}^{2} / \mathrm{m}^{3}$ of media volume, on which a stable biomass can grow, combining the best characteristics of the activated sludge technology with a stable carrier element. The EEC

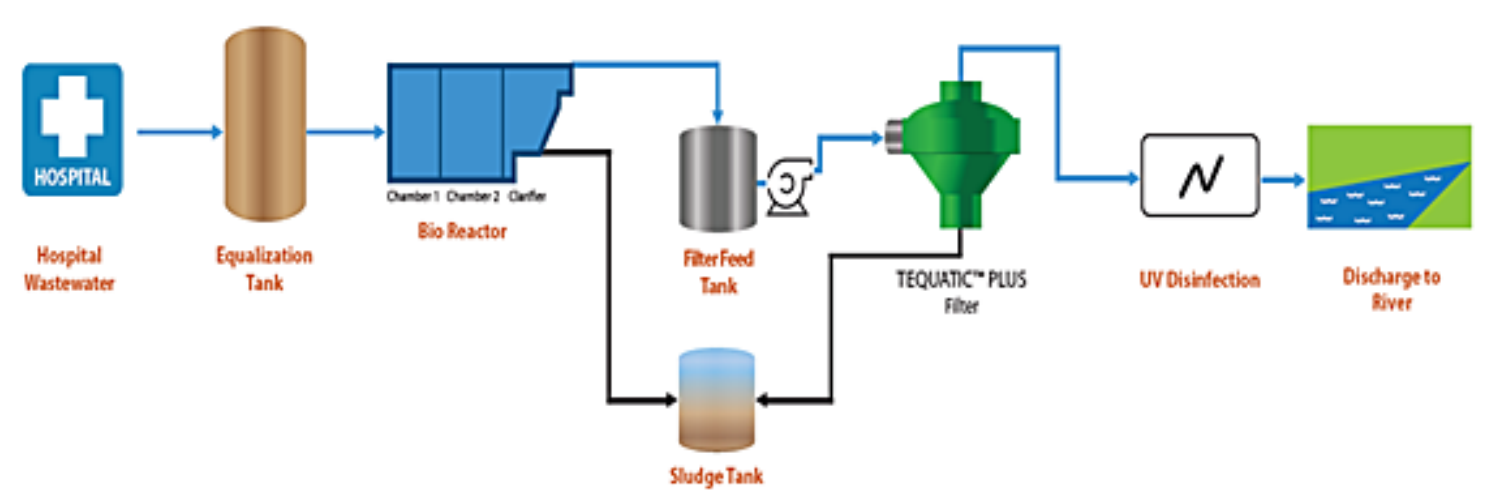

Fig. 1. The schematic of EEC USA packaged MBBR system 
AMB Biomedia was made of plastic that has a long expected lifetime in water. The Biomedia was made from extruded tube cuttings with an internal cross and has 25 external low fins. The nominal dimensions are the dioamter of $12 \mathrm{~mm}$ and the length of $10 \mathrm{~mm}$. The surface to volume ratio is approximately $850 \mathrm{~m}^{2}$ per $\mathrm{m}^{3}$ of Biomedia in bulk. $50 \%$ of the tank volume was occupied by elements.

Raw wastewater was obtained from the collection equalization basin of Al-Batool Teaching Hospital as influent to the system. The raw wastewater was screened with a $0.75 \mathrm{~cm}$ opening screener.

\section{Operation conditions}

The MBBR system operates with a flow rate of $6 \mathrm{~m}^{3} / \mathrm{hr}$, corresponding to a hydraulic retention time (HRT) of $4.1 \mathrm{hr}$. The mass liquor suspended solids (MLSS) was maintained within the range of $1400 \pm 200 \mathrm{mg} / \mathrm{L}$ with a temperature of $18 \pm 3$ ${ }^{\circ} \mathrm{C}$. The $\mathrm{pH}$ value was within the range of 6.8-8.2.

\section{Analytical methods}

Each analytical parameter was tested once a week. Each tested value represented the average value of three gathered samples. The analysis of TSS, MLSS and sludge volume index (SVI) were conducted using the procedures recommended by
APHA, (2005). The $\mathrm{BOD}_{5}$ was estimated with the aid of the OX Direct control system, Germany. Lovibond water testing photometer system MD200, Germany was used for testing COD. Dissolved oxygen (DO) was measured using Lovibond SensoDirect OXi200, Germany. Hanna Instruments were used for measuring the $\mathrm{pH}$. The analysis of $\mathrm{NH}_{4}-\mathrm{N}$ was measured using Potentiometric Titration Titroprocessor, MD 686, Swesra. The analysis of $\mathrm{NO}_{3}-\mathrm{N}$ was measured using a UV-Visible Recording Spectrophotometer, MD UV-160A- Japan.

\section{RESULTS AND DISCUSSIONS}

Typical compositions of the influent wastewater are given in Table (1). As shown in this table as well as Figures 2 and 3, in spite of the fluctuation in the influent organic load, the average effluent of $\mathrm{BOD}_{5}$ and COD was 28.4 and $46.7 \mathrm{mg} / \mathrm{l}$, corresponding to $79.5 \%$ and $74.5 \%$, respectively. These outcomes are in a good agreement with (Andreottola et al., 2000; Yogita S. and Mitali J., 2015; Husham et al., 2014) which found that the BOD removal efficiency ranges between 79 to $82 \%$ and $76 \%$ of COD removal efficiency.

The effluent TSS of the MBBR system was stable within the range of 23.4 to $38 \mathrm{mg} / 1$ with the average value of $29.6 \mathrm{mg} / \mathrm{l}$, corresponding to $78 \%$ removal efficiency, as shown in Figure 4. These

Table 1. Typical compositions of the influent wastewater

\begin{tabular}{|l|c|c|c|c|c|c|c|c|c|c|c|}
\hline Items & $\begin{array}{c}\mathrm{BOD}_{5} \\
(\mathrm{mg} / \mathrm{l})\end{array}$ & $\begin{array}{c}\mathrm{COD} \\
(\mathrm{mg} / \mathrm{l})\end{array}$ & $\begin{array}{c}\mathrm{PO}_{4} \\
(\mathrm{mg} / \mathrm{l})\end{array}$ & $\begin{array}{c}\mathrm{NH}_{4} \mathrm{~N} \\
(\mathrm{mg} / \mathrm{l})\end{array}$ & $\begin{array}{c}\mathrm{NO}_{3}-\mathrm{N} \\
(\mathrm{mg} / \mathrm{l})\end{array}$ & $\begin{array}{c}\mathrm{TSS} \\
(\mathrm{mg} / \mathrm{l})\end{array}$ & $\begin{array}{c}\mathrm{O} \& \mathrm{G} \\
(\mathrm{mg} / \mathrm{l})\end{array}$ & $\begin{array}{c}\mathrm{pH} \\
(-)\end{array}$ & $\begin{array}{c}\mathrm{EC} \\
(\mu \mathrm{S})\end{array}$ & $\begin{array}{c}\mathrm{SO}_{4} \\
(\mathrm{mg} / \mathrm{l})\end{array}$ & $\begin{array}{c}\mathrm{TDS} \\
(\mathrm{mg} / \mathrm{l})\end{array}$ \\
\hline Range & $84.7-260$ & $130-305$ & $1.6-4.3$ & $25.8-89$ & $0.5-6.5$ & $105-158$ & $7.5 \pm 3$ & $7.8-8.1$ & $1855 \pm 100$ & $173 \pm 10$ & $1048-1287$ \\
\hline Avrage & 147.2 & 194.6 & 2.8 & 51.3 & 1.73 & 135 & 7.5 & 8.0 & 1855 & 173 & 1117 \\
\hline
\end{tabular}

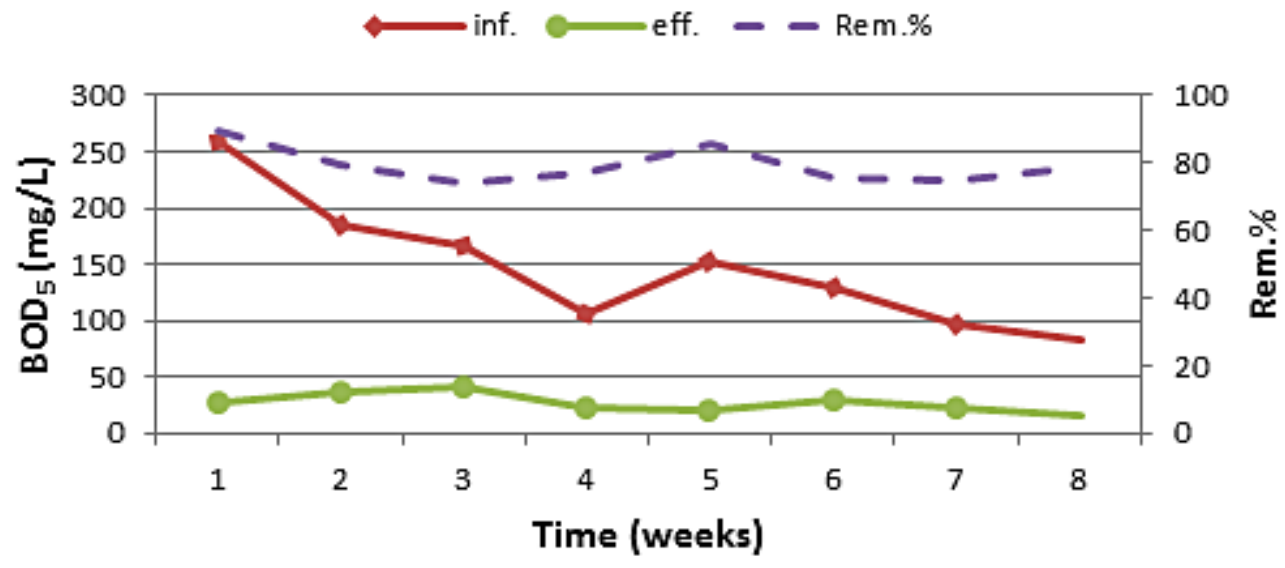

Fig. 2. Influent, effluent and removal efficiency of BOD 


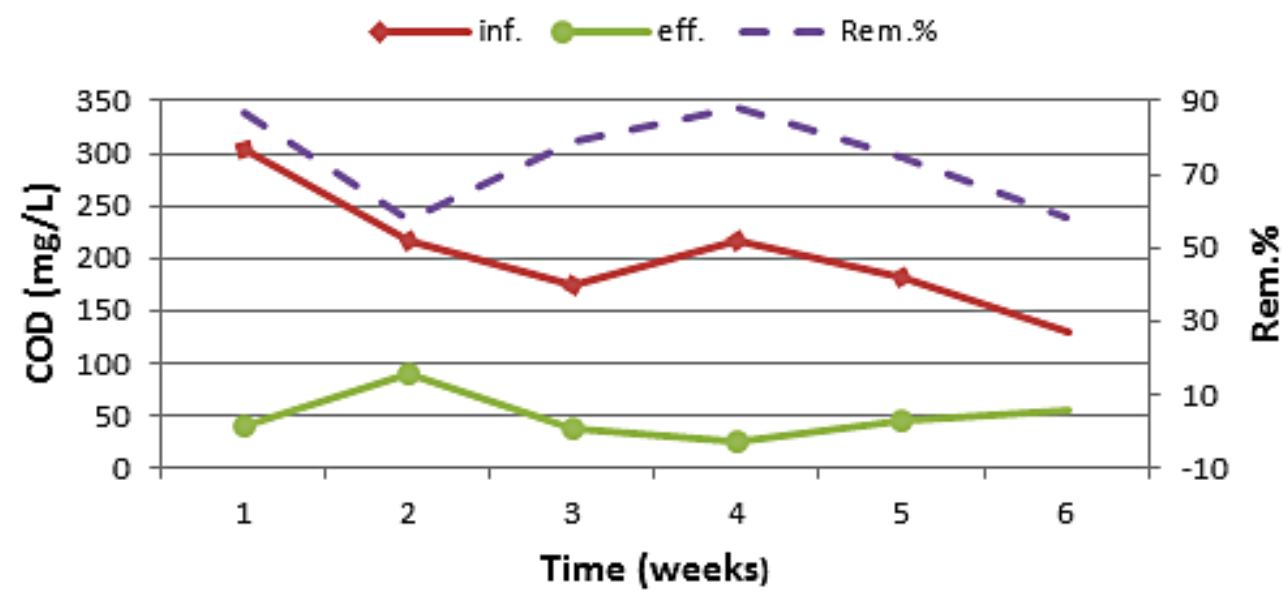

Fig. 3. Influent, effluent and removal efficiency of COD

results seems to be in an agreement with another study (Andreottola et al., 2000), which reported that the effluent TSS of the MBBR system within the range of $6-37 \mathrm{mg} / \mathrm{l}$.

Figures 5 and 6 illustrate the influent and effluent of $\mathrm{NH}_{4}-\mathrm{N}$ and $\mathrm{NO}_{3}-\mathrm{N}$ as a function of time, respectively. It is clear that approximately $80 \%$ of ammonia was converted to nitrate. This indicates that a good nitrification occurs in the MBBR system. On the basis of the summation of influent and effluent nitrogen content, the nitrogen removal efficiency was only $29.4 \%$ due to the absence of anoxic zone in MBBR system. The nitrogen removal at this point was attributed to the denitrification in the anoxic zone which exists in the deep layers of the attached biofilm, in addition to the nitrogen removal by cell metabolisms.

In the MBBR strategy, that over $90 \%$ of biomass is likely caught and cultivated in the media as opposed to being suspended in the liquid (Schmidt and Schaechter, 2011). In this study, the
MBBR system shows a weak formation of biomass on carriers, with only $1.93 \mathrm{~g} \mathrm{TSS} / \mathrm{m}^{2}$ of media, corresponding to $32 \%$ of the suspended biomass in the reactor. This finding might be due to the low organic load $\left(0.965 \mathrm{~kg} / \mathrm{m}^{3}\right)$, which leads to endogenous decay of the attached biomass. Aygun et al. (2008) found that an increase in the organic loading rate will prompt the increase in the amount of biomass attached to the carrier. Perhaps for this reason, the EEC USA packaged wastewater treatment plant, in this case, recirculates biomass to the first chamber.

Palm et al. (1980) reported that the SVI did not surpass the value of $150 \mathrm{~mL} / \mathrm{g}$, which can indicate good settling properties of the sludge. Sludge having SVI more than $150 \mathrm{~mL} / \mathrm{g}$ is often categorized as bulking sludge. In this experiment, the SVI values were below $100 \mathrm{~mL} / \mathrm{g}$ for all experiments, except for the second value, as shown in Figure 7. This indicates that the sludge is dense and has rapid settling characteristics.

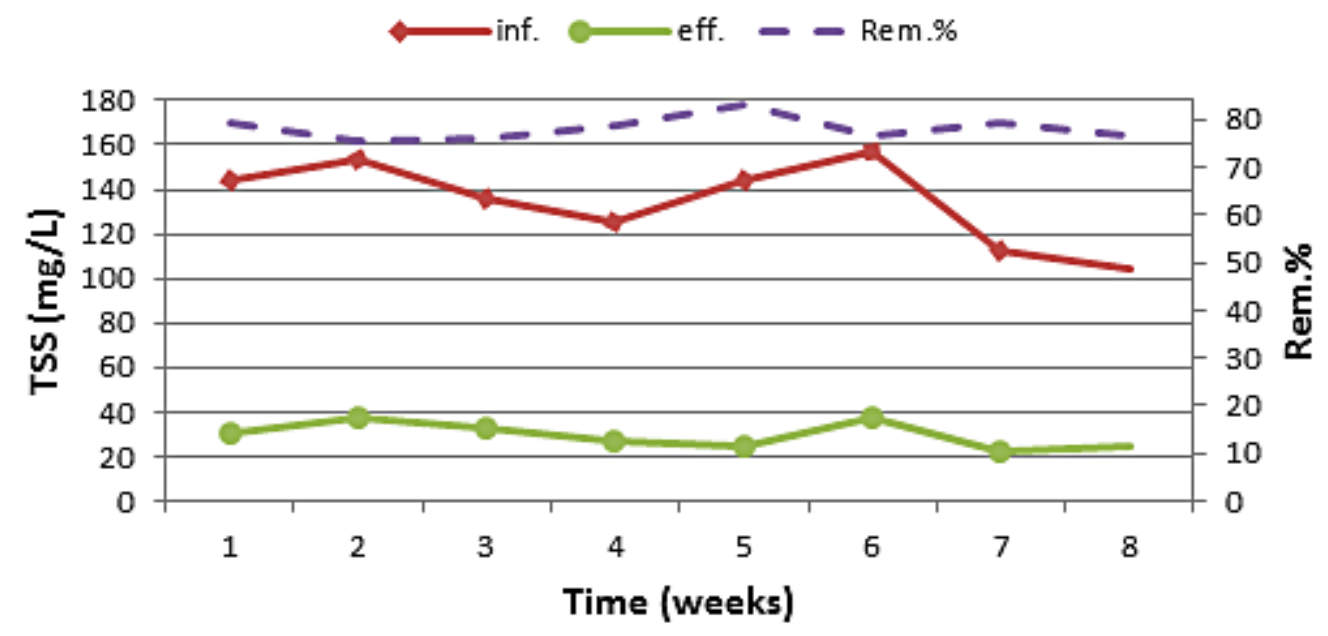

Fig. 4. Influent, effluent and removal efficiency of TSS 


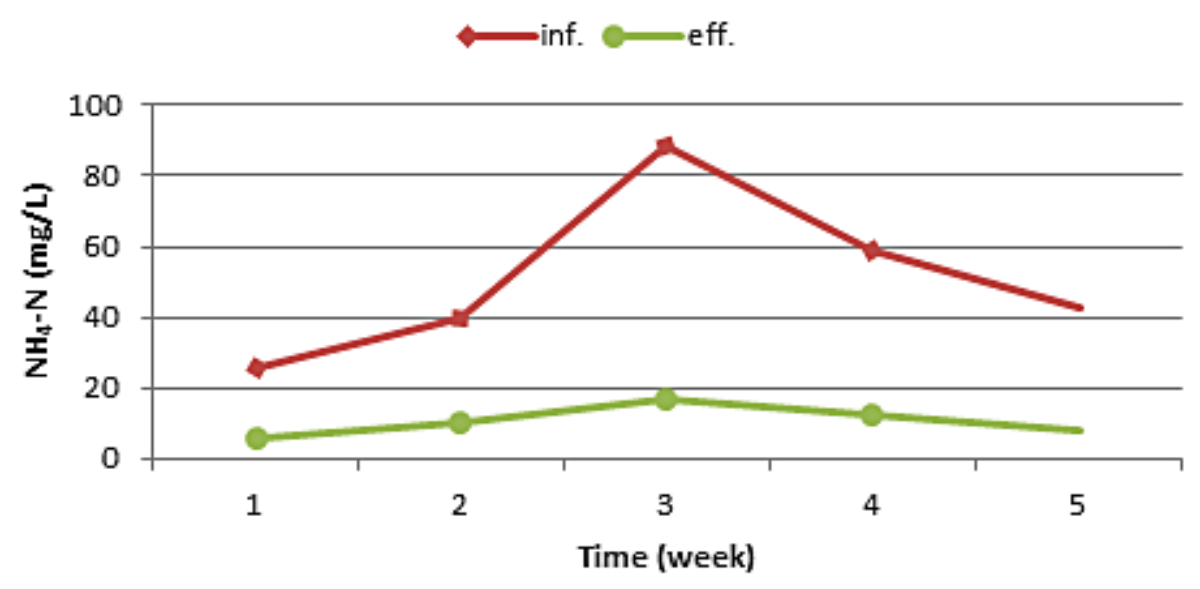

Fig. 5. Influent and effluent $\mathrm{NH}_{4}-\mathrm{N}$

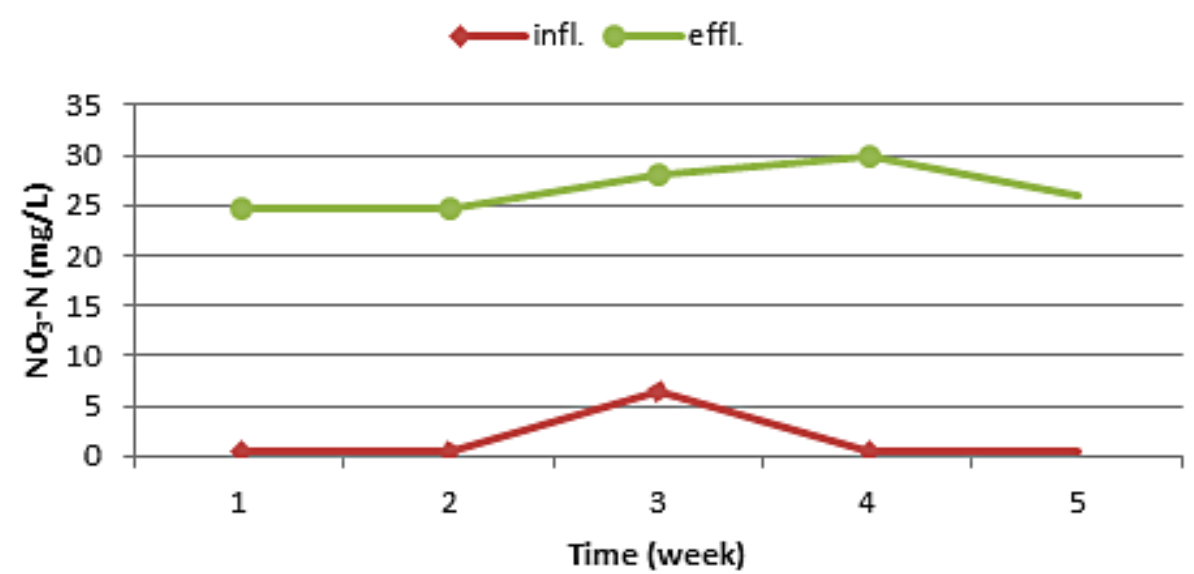

Fig. 6. Influent and effluent $\mathrm{NO}_{3}-\mathrm{N}$

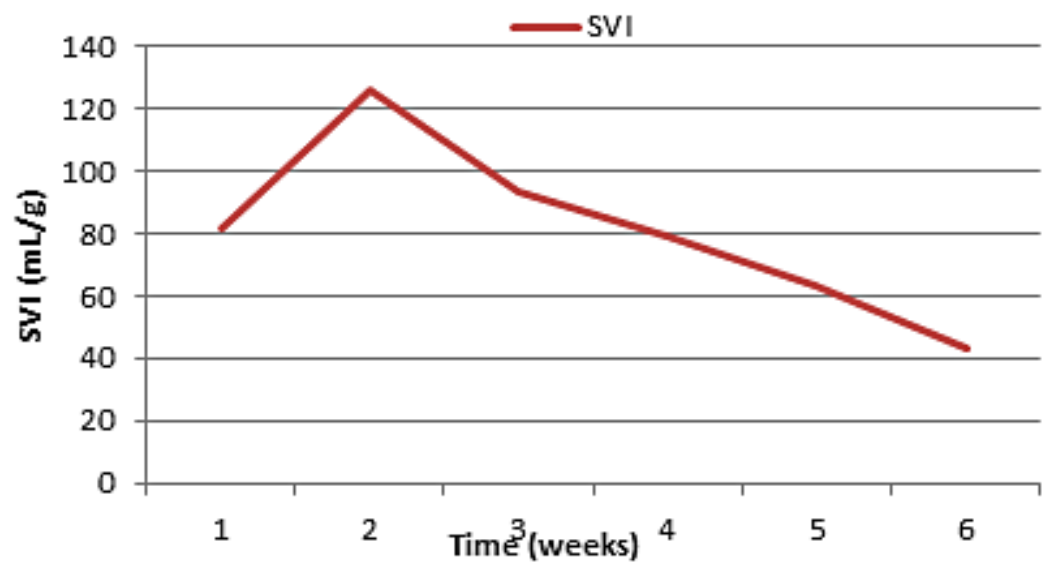

Fig. 7. The variation of SVI for MBBR experiment

\section{CONCLUSIONS}

Since biofilm plays an essential role in degrading pollutants in MBBR systems, any challenge to the growth of biofilm reduces the efficiency of the treatment process. The present study showed that the MBBR system was not perfect in terms of organic matter removal, compared to the activated sludge process, which might be due to the low MLSS and detachment of biomass from carriers. Nevertheless, the tested system is well suited for meeting the requirements pertaining to the limitations of rivers maintenance from pollution for effluent of organic matter and TSS. 
The system shows a weak formation of biomass on carriers. The reduction in TDS was not significant. The tested system yields the sludge with good settling properties.

\section{Acknowledgements}

The authors gratefully acknowledge the support provided by Al- Batul hospital staff for his assistance during the research and for supplying with samples and analysis.

\section{REFERENCES}

1. Ahmet A., Bilgehan N., Ali B. 2008. Influence of High Organic Loading Rates on COD Removal and Sludge Production in Moving Bed Biofilm Reactor. Environmental Engineerig Science, 25 (9), 1311-1316.

2. American Public Health Association, APHA. 2005. Standard Methods for the Examination of Water and Wastewater. Washington, D.C: APHA. (21th ed.).

3. Andreottola G., Foladori R., Ragazzi M., Tatano F. 2000. Experimental comparison between MBBR and activated sludge system for the treatment of municipal wastewater. Water Science \& Technology, 41 (4-5), 383-391.

4. Biswas K., Taylor M.W., Turner S.J. 2014. Successional development of biofilms in moving bed biofilm reactor (MBBR) systems treating municipal wastewater., Appl Microbiol Biotechnol, 98(3), 1429-1440.

5. Borkar R.P., Gulhane M.L., Kotangale A.J. 2013. Moving Bed Biofilm Reactor - A New Perspective in Wastewater Treatment. Journal Of Environmental Science, Toxicology And Food Technology, 6(6), 15-21.

6. Ekhaise F.O. and Omavwoya B.P. 2008. Influence of Hospital Wastewater Discharged from University of Benin Teaching Hospital (UBTH), Benin City on its Receiving Environment. American-Eurasian J. Agric. \& Environ. Sci., 4(4), 484-488.

7. Emmanuel E., Perrodin Y., Keck G., Blanchard M., Vermande P. 2005. Ecotoxicological risk assessment of hospital wastewater: a proposed framework for raw effluents discharging into urban sewer network. Journal of Hazardous Materials, 117(1), 1-11.

8. Gautam A.K., Kumar S., Sabumon P. 2007. Preliminary study of physicochemical treatment options for hospital wastewater. Journal of Environmental Management, 83(3), 298-306.

9. Husham T.I., He Q. and Wisaam S. Al-Rekabi. 2014. Simultaneous Organics and Nutrients Re- moval from Domestic Wastewater in a Combined Cylindrical Anoxic/Aerobic Moving Bed Biofilm Reactor. Research Journal of Applied Sciences, Engineering and Technology, 7 (9), 1887-1895.

10. Kajitvichyanukul P., Lu M., Liao C., Wirojanagud W., Koottatep, T. 2006. Degradation and detoxification of formaline wastewater by advanced oxidation processes. Journal of Hazardous Materials, 135 (1-3), 337-343.

11. McQuarrie J.P., Boltz J.P. 2011. Moving bed biofilm reactor technology: process applications, design, and performance. Water Environment Research, 83(6), 560-575.

12. Ødegaard H. 1999. The moving bed biofim reactor. Water Environmental Engineering and Reuse of Water, (250-305), 12.

13. Ødegaard H. 2000. Advanced compact wastewater treatment based on coagulation and moving bed biofilm processes. Water Science and Technology, 42(12), 33-48.

14. Pal S. R., Dr. Dipak S.V., Arti N.P. 2016. Study the efficiency of moving bed bio-film reactor (MBBR) for dairy wastewater treatment. IJARIIE, 2(3), 2395-4396.

15. Palm, J.C., Jenkins, D. and Parker, D.S., 1980. Relationship between organic loading, dissolved oxygen concentration and sludge settleability in the completely-mixed activated sludge process. J. Water Pollut. Control Fed., 52 (10), 2484-2506.

16. Punmia B. C., Jain A. 2003. Wastewater Engineering: Laxmi Publications (P) LTD, Delhi-51.

17. Schmidt T.M., Schaechter M. (Eds.) 2011. Topics in ecological and environmental microbiology. (3rd ed.) Academic Press, UK.

18. Suarez S., Lema J., Omil F. 2009. Pre-treatment of hospital wastewater by coagulation-flocculation and flotation. Bioresource Technology, 100(7), 2138-2146.

19. Tatiana P., Dalton M., Guilayn C., Rose L., Maria A., Miagostovich P. 2011. Quantification and molecular characterization of enteric viruses detected in effluents from two hospital wastewater treatment plants. Water Research, 45(3), 1287-1297.

20. Verlicchi P., Galletti A., Petrovic M., Barcelo D. 2010. Hospital effluents as a source of emerging pollutants: An overview of micropollutants and sustainable treatment options. Journal of Hydrology, 389(3-4), 416-428.

21. Westerling K. 2014. Biological treatment 101: suspended growth vs. attached growth. Retrieved 22 July, 2015, from http://www.wateronline.com/ doc/biological-treatment-suspended-growth-vsattached-growth-0001

22. Yogita S., Mitali J. S. 2015. Lab scale study on moving bed biofilm reactor- an effective perspective in biological wastewater treatment. IJARESM, 1(5), 1-7. 